\title{
THE NATIONAL LANDSLIDE DATABASE OF GREAT BRITAIN: DEVELOPMENT, EVOLUTION AND APPLICATIONS
}

\author{
Foster, C. ${ }^{1}$, Pennington, C. V. L. ${ }^{1}$, Culshaw, M. G. ${ }^{2}$ and Lawrie, K. ${ }^{3}$ \\ 1 British Geological Survey, Keyworth, Nottingham, UK \\ 2 School of Civil Engineering, University of Birmingham, Edgbaston, Birmingham, UK and \\ British Geological Survey, Keyworth, Nottingham, UK \\ 3 British Geological Survey, Edinburgh, UK \\ Corresponding Author ${ }^{1}$ British Geological Survey, Keyworth, Nottingham, Nottinghamshire, \\ NG12 5GG, United Kingdom. 0115 9373404.cfoster@bgs.ac.uk
}

\begin{abstract}
Landslide inventories are essential because they provide the basis for predictive landslide hazard and susceptibility assessments and because they allow for the manipulation and storage of temporal and spatial data. The National Landslide Database has been developed by the British Geological Survey (BGS). It is the most extensive source of information on landslides in Great Britain with over 15000 records of landslide events each documented as fully as possible. This information is invaluable for planners and developers as it helps them investigate, avoid or mitigate areas of unstable ground in accordance with Government planning policy guidelines. Therefore, it is vital that the continual verification, collection and updating of landslide information is carried out as part of the Survey's 'National Capability' work. This paper describes the evolution from a static database to one that is continually updated forming part of a suite of national digital hazard products. The history of the National Landslide Database and associated Geographical Information System (GIS) is discussed, together with its application and future development.
\end{abstract}

Keywords: Landslide, database, GIS, planning.

\section{INTRODUCTION}

Landslides are a worldwide phenomenon with significant social and economic side effects. However, they are often under-reported due to their occurrence being linked to more conspicuous hazards such as earthquakes and tropical 
storms (Lee \& Jones 2004). McGuire et al. (2002) observed that "Landslides are the most widespread and undervalued natural hazard on earth". Of the landslides that are reported, data (sourced from the International Disaster Database: CRED, 2009) showed that between 1903 and 2009 Europe had a relatively low number of landslide events, but suffered the most significant economic damage outside the Americas. One of the worst hit countries within Europe is Italy, which is subject to an estimated 400 landslides a year with a total cost of $€ 120 \mathrm{~m}$ (European Space Agency, 2005). In Spain, increasing numbers of landslides led to economic losses of €36m/year during the 1990s (European Environment Agency 2003). Landsliding does not occur at these levels or have such severe consequences in Great Britain, but there have been numerous events in recent years, such as those on the A85 road in Scotland (Winter et al, 2005; British Geological Survey 2009a), Cayton Bay in Yorkshire (Fish et al. 2006; British Geological Survey 2009b) and on the south coast of England at Lyme Regis (British Geological Survey 2009c) These occurrences have highlighted the continued need to produce landslide information for a wide range of users in Great Britain.

The first step towards producing a landslide susceptibility map is through the creation of a landslide inventory (Casagli et al., 2004). Landslide inventories can be prepared to fulfil a number of objectives, including assessing the effects of a single landslide trigger such as an earthquake (Duman et al, 2005), displaying the spatial abundance of mass movements (Guzzetti et al. 2008), determining the frequency-area statistics of slope failures (Turcotte et al. 2005) and providing relevant information to construct landslide susceptibility and hazard maps (Galli \& Guzzetti 2007). However, landslide inventories probably are most frequently used to display the locations and types of landslides and to provide the basis for analysing their spatial distribution and their causal factors. With the development of geographical information systems (GIS), understanding the patterns of landsliding and the factors controlling this distribution has become easier, allowing for the production of more complex hazard assessments.

The international importance of landslide inventories was highlighted at the Fifth International Landslide Symposium in Lausanne (Switzerland). Here the Working Party on the World Landslide Inventory was initiated to develop a detailed list of the world's landslides (Cruden \& Brown 1992). The World Landslide Inventory was established to aid the United Nations in understanding the distribution of landslides. This is essential for the implementation of mitigation strategies and to plan for future landslide events. Progress on the development of a global landslide inventory was further strengthened in 2003 by the initiation of a Cooperation Programme. This brought together the International Consortium on Landslides (ICL), Kyoto University and the United Nations Educational, Scientific and Cultural Organisation (UNESCO) with the aim of promoting research and training in landslides for the benefit of society. One of the principle objectives of the programme was to develop a landslide database and digital global landslide inventory (International Consortium on Landslides 2006).

Prior to the launch of the global landslide inventory, many countries had already developed their own landslide datasets; these were generally managed by national or state geological surveys, government departments or their equivalents. For example, the Australian landslide database, managed by Geoscience Australia, brings together three separate inventories and has concentrated on improved interoperability (Osuchowski \& Atkinson 2008). The on-line database and map represents the spatial distribution of over 1000 landslides based on published and unpublished information plus field observations. Whilst the Australian example concentrates on landslide location and attribution, the Hong Kong landslide inventory has used statistical correlations of landslide frequency and terrain variables to allow the production of landslide susceptibility maps (Dai \& Lee, 2002). Landslide inventories are commonplace in Europe but there is variability in the complexity and amount of further work carried out on landslide susceptibility or hazard map production. The European EPOCH (European Programme on Climate and Natural Hazards) project, which ran between 1991 and 1993, established the availability of data on landslide occurrence and how these data were stored (Flageollet 1993; Dikau et al. 1996). Results showed that, at the time, seven European countries had landslide databases and associated GIS’s: France, Germany, Italy, Spain, the UK, the Netherlands and Switzerland. Since then, further developments in Europe have seen Bulgaria, the Czech Republic, Cyprus, Romania, Slovakia and Slovenia join the European Community, each with its own landslide inventory (Jelínek et al. 2007). Our paper discusses the history of landslide inventory development in Great Britain and outlines the way in which the database has been designed.

\section{DRIVERS FOR LANDSLIDE RESEARCH IN GREAT BRITAIN}

Despite the relative low frequency of high-impact landslides in Great Britain, the existing land-use planning guidance and building regulations make further research necessary because knowledge of landslide distribution and susceptibility is incomplete and inconsistent. The relatively subdued topography and degraded nature of many ancient failures in Great Britain meant that landsliding was not widely considered to be extensive or problematic. However, costly disruptions to projects in the 1960s by reactivation of previously unknown landslides, for example, on the Sevenoaks By-pass (Skempton \& Weeks 1976) and the Walton's Wood motorway embankment (Early \& Skempton 1972), brought about a realisation that the extent of ground instability was not well understood or managed by developers or planners. In the 1980s, the British planning system focussed on social and economic 
considerations; physical processes and ground conditions were considered to be the responsibility of other control systems and few developers or planners fully understood the processes and conditions in their area (Brook 2002). With increased development, both in and around urban areas and for communication links and utilities, the pressure on land became greater and the identification of landslides and potentially susceptible locations became much more significant. To reduce the risks associated with potentially unstable ground, the identification of both known failures and susceptible areas became vital. To provide guidance for land-use planners, to assist in the recognition of adverse physical ground conditions and to mitigate against their consequences, the UK Government's Department of the Environment (DoE) initiated a series of national reviews and research programmes in the 1980s and 90s (Brook 2002). These reviews included research into the extent of adverse ground conditions such as those caused by landsliding, mining instability, natural ground cavities and contamination. The first national assessment of landsliding was undertaken as part of this programme.

Between 1984 and 1989, a desk study was undertaken by Geomorphological Services Limited (GSL) to establish the extent of landsliding in Great Britain. Part of this study involved the creation of a landslide database (henceforth referred to as the 'DoE database'), which, on completion, held 8835 landslide records (Geomorphological Services Ltd 1989). The final total far out-weighed the initial estimate of 1000 landslides, highlighting how much landsliding had previously been under-estimated, even by experts (Jones \& Lee 1994). The research and review programme resulted in the publication of Planning Policy Guidance Note 14 (PPG14) along with Appendix A (Department of the Environment (DoE) 1990, 1996). The Appendix set out the procedure for landslide recognition and hazard assessment and emphasised the need to consider ground instability throughout the whole development process from land-use planning, through design to construction.

The production of the DoE database was a much-needed first step in identifying the extent and significance of landslides in Great Britain, but it did suffer from a number of deficiencies. Some of the problems with the database were a product of the data collection method. Landslide records were sourced from reports and journals plus BGS published geological maps and memoirs, which clearly limited the content of the database to failures that had previously been recorded. The population of the database, purely from published sources, also created a skew to areas where active landslide research and modern geological surveying had been carried out, whilst more remote and often less researched areas were probably under-reported. This original database was completed by 1990 and no further landslides were uploaded creating a static inventory.

Since 1995, the DoE database has been incorporated into the new National Landslide Database (NLD), which was developed and is managed by the BGS. In developing the NLD, the BGS sought to overcome the problems identified with the original DoE database. The results of an analysis of the DoE database were published in Jones \& Lee (1994) and, in a reflective review, Jones (1998) highlighted some of the problems associated with the production of a landslide inventory through a desk study approach. One of the issues highlighted was that "Landslide mapping efforts were not consistent across Great Britain" leading to areas of apparent concentrated landslide activity simply reflecting the results of detailed studies. Areas of high landslide concentration such as South Wales (Conway et al. 1980), South East England (Hutchinson 1976), Torbay in Devon (Doornkamp, et al. 1988) and the Jurassic escarpment of the South Midlands of England (Chandler 1970) were juxtaposed against areas with very limited landslide data. BGS has addressed this issue by identifying areas with conspicuously low landslide numbers and carrying out a systematic resurvey of these areas, for example in parts of the Pennines of northern England and the catchment of the River Thames, which includes London and areas to the west. Another issue highlighted by Jones (1998) was that "No distinction is made on the dot distribution map between small landslides and more extensive areas of landsliding." This issue has been addressed in the NLD by the linking of digital landslide polygons from the geological maps of the country to the landslide database. This has meant that, where mapped, each landslide record has a corresponding landslide polygon, showing the spatial extent of the failure (Fig 1). Jones (1998) also mentioned in the review that "Information is gathered from a number of different sources, which means there is never a 'standard landslide'." To address this BGS has introduced a landslide proforma to standardise data collection and interpretation (subsequently discussed in more detail). 


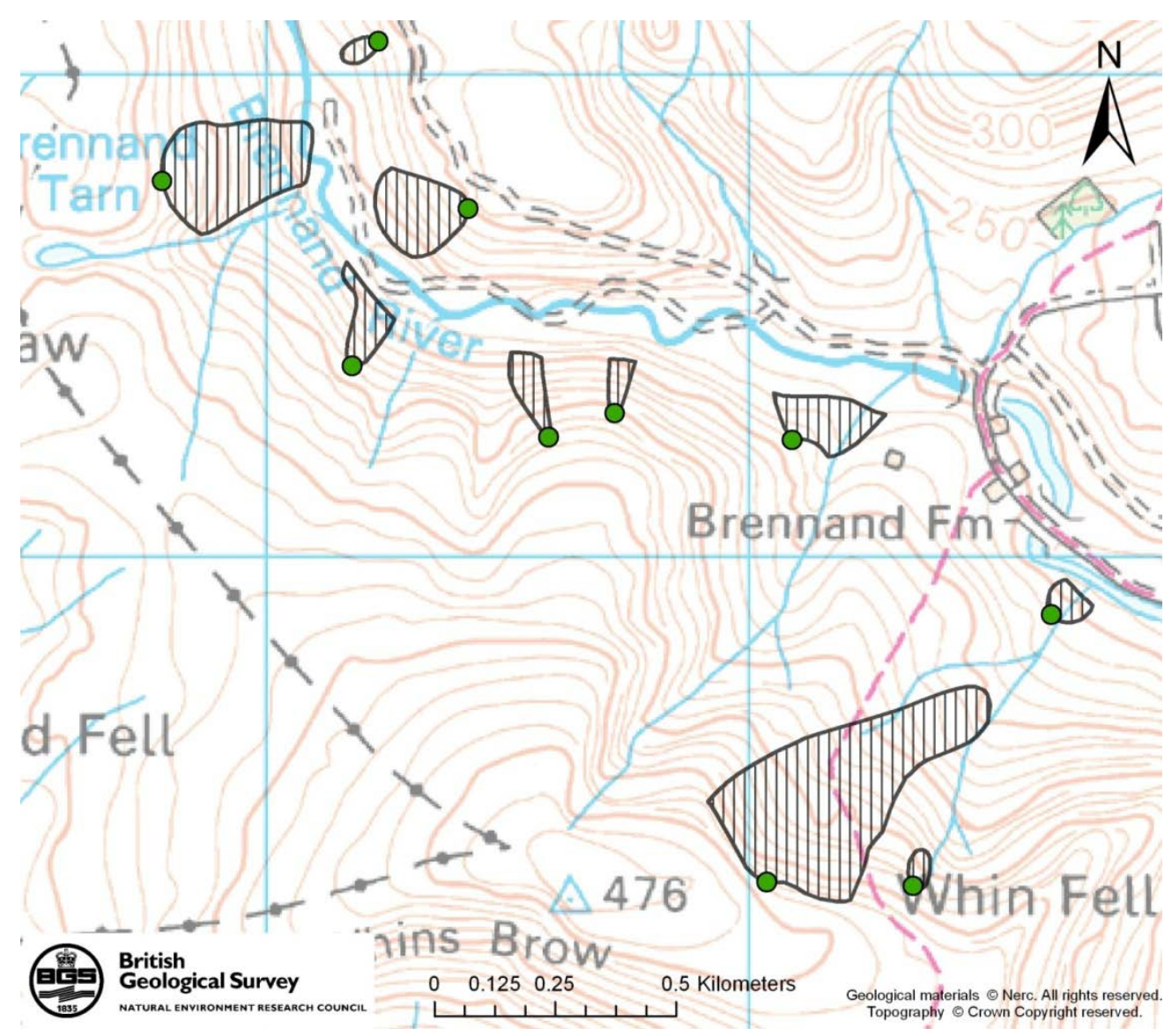

Figure 1. Map of landslides (black vertical hashing) from digital geological map of Great Britain at 1:50 000 scale and associated NLD points (green). OS topography (C) Crown Copyright. All rights reserved.

$100017897 / 2010$

\section{DRAWBACKS OF THE DOE DATABASE}

As the DoE database was developed during the 1980s, it was held in a rigid MS-DOS format that is neither userfriendly nor flexible. More recently, 'personal relational databasing systems' have become commonplace and have superseded all such early systems.

At a design level the format used for the DoE database presents several operational, data and systemic problems. Operationally, this system is now entirely obsolete and any capacity to develop within its constraints is hampered by a lack of documentation and expertise in such an old system. In terms of data, the system is rather rigid and inflexible and would require considerable development and research time to make even the slightest alteration to the product.

The main drawbacks of the DoE database are:

- $\quad$ the system was originally designed in 1984/5 and reflects, to some extent, what was possible on a personal computer (PC) at the time. True Relational Data Base Management Systems (RDBMS) for PCs were in their infancy and relational systems designers were a much rarer breed then;

- $\quad$ it is a 'black box' system, an effectively standalone system, which is neither easily expandable nor easily capable of integration or use with modern products.

As a user interface, it is awkward to use:

- $\quad$ each landslide record is viewed over several pages meaning that only one part of a record could be viewed at a time;

- there is no geographical visual display of the data. It is almost impossible to spatially search effectively for landslides. 
- $\quad$ it mixes relational and flat-file structures meaning that there is significant redundancy (it is 'de-normalised' in database terminology); even the more relational structures within it are seriously relationally compromised by its structure;

- $\quad$ to effectively query the data within the database, there is a need to predefine the criteria required and then to embed the functionality using code; ad-hoc querying is not fully supported. The system does not support Structured Query language (SQL) - the lingua franca of modern databases

- the constraining dictionaries are code based and very inflexible indeed, they are very difficult to manage, expand and alter; they often represent a snapshot in time and many of the codes are not appropriate for today;

- $\quad$ to use the coded values properly requires the user to 'look-up' those values in a separate document to ascribe meaning; this represents a significant cost in time to the user.

Others issues arose with the DoE database once it had been produced. To sustain the database, the business model proposed that the data be sold to external users and the income obtained used to continually update it. However, the database did not provide sufficient income to allow this to take place. The DoE database was managed by a geotechnical consultancy (now High Point Rendel) which had taken-over GSL Ltd and, eventually, the database ceased to be maintained.

As a result of the deficiencies in the original database, it has proved to be far more cost effective to build the NLD from scratch, in a properly designed and constrained modern RDBMS, but the DoE database has been used to inform the NLD.

\section{THE BGS NATIONAL LANDSLIDE DATABASE AND GIS OF GREAT BRITAIN}

The NLD is the most comprehensive source of information on landslides in Great Britain and currently holds records of over 15000 landslide events, an increase of over 6000 landslide entries over the DoE dataset. The objectives set for the NLD were to create an applied database, incorporating and adding to data in the DoE database, that could be easily accessed, queried and displayed; there needed to be a system for populating, maintaining, updating and developing the database. The intention was that the database should be accessible to the general public as well as professionals. With this in mind, a data-capture 'front-end' was created as a highly modified Microsoft Access ${ }^{\odot} 2003 / 2007$ database system attached directly to an Oracle ${ }^{\odot}$-based corporate data store. The Oracle ${ }^{\odot}$ database is 'live-linked' to a relational GIS.

Each of the $15000+$ landslide event records can hold information on over 35 attributes including location, dimensions, landslide type, trigger mechanism, damage caused, slope aspect, material, movement date, vegetation, hydrogeology, age, development and a full bibliographic reference. The information within the NLD is corporately maintained and held in a digital format that can be adapted and updated so it will be useable for decades to come.

\section{DATA COLLECTION}

The DoE database was originally populated from secondary sources including maps, other databases, reports, research theses and newspaper articles. Data in the NLD come from a variety of sources. Approximately 10000 landslides in the NLD have been sourced from BGS geological maps for which the original mapping was carried out mostly at a scale of 1:10 000. Other landslide mapping projects undertaken by BGS have also been incorporated into the database, including specialised landslide studies in the Afon Teifi catchment of south west Wales, the South Wales Coalfield and Bradford in Yorkshire. To ensure the continual population of the database with previously unknown or new events, strategic data collection is carried out. There are two main methods for data capture: desktop research and in the field through BGS·SIGMA mobile technology (Jordan 2009; Jordan et al. 2005), which allows dynamic field capture of fully attributed and relational data through a GIS system. The BGS also monitors live news feeds and is set up to respond quickly to significant landslide events seven days a week. Information from these live news feeds is entered into the NLD if it can be verified; alternatively, it is stored in a separate database for landslide events reported in the media. The main landslide data sources used for the NLD are summarised in Table 1. 


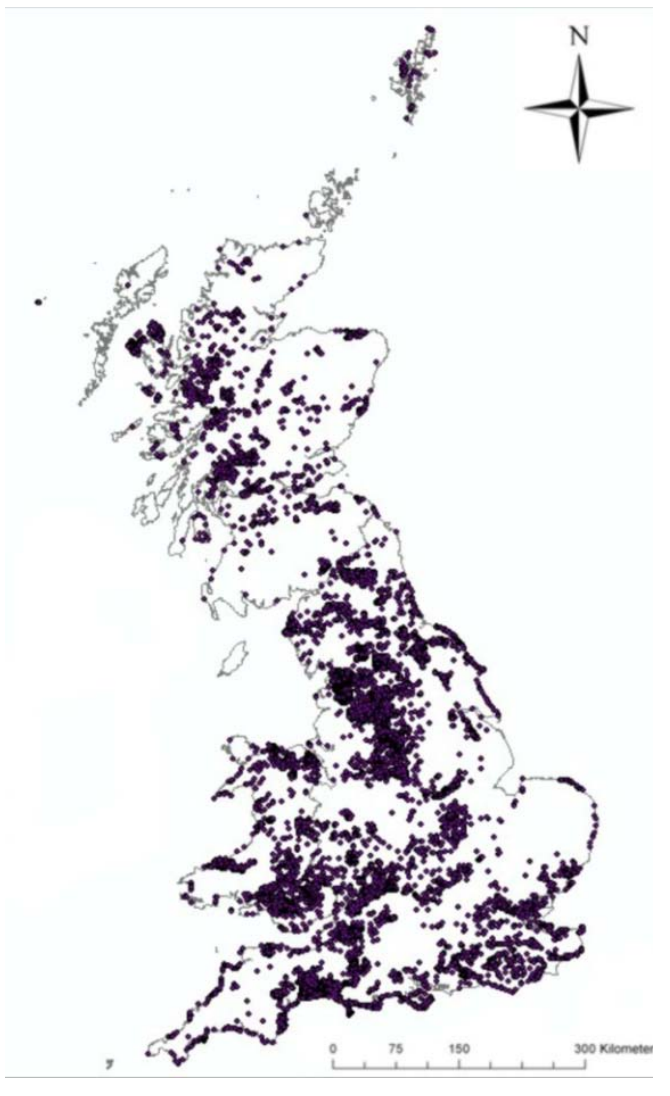

Figure 2. Distribution of landslide database points from the National Landslide GIS database. OS topography (C) Crown Copyright. All rights reserved. 100017897/2010

Table 1. Sources of information for the NLD

\begin{tabular}{|c|c|c|c|}
\hline BGS Maps & \multicolumn{2}{|c|}{ BGS other sources } & External \\
\hline \multirow[t]{2}{*}{$\begin{array}{l}\text { 1:10 } 000 \text { scale DigMap } 10 \text { mass } \\
\text { movement polygons }\end{array}$} & \multirow{8}{*}{ 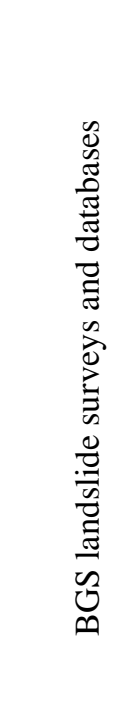 } & $\begin{array}{l}\text { Afon Teifi, } \\
\text { Wales }\end{array}$ & $\begin{array}{l}\text { GSL National Landslide Database } \\
\text { ('DoE database') }\end{array}$ \\
\hline & & Calderdale, & \\
\hline \multirow{2}{*}{$\begin{array}{l}\text { 1:50 } 000 \text { scale DigMap50 mass } \\
\text { movement polygons }\end{array}$} & & Yorkshire & \multirow{2}{*}{$\begin{array}{l}\text { Books, reports, published papers and } \\
\text { conference proceedings }\end{array}$} \\
\hline & & \multirow[b]{2}{*}{$\begin{array}{l}\text { Bradford, } \\
\text { Yorkshire }\end{array}$} & \\
\hline $\begin{array}{l}\text { 1:10 } 000 \text { scale mapped landslide } \\
\text { deposits }\end{array}$ & & & Site investigation reports \\
\hline $\begin{array}{l}\text { 1:10 } 560 \text { scale mapped landslide } \\
\text { deposits }\end{array}$ & & $\begin{array}{l}\text { South Wales } \\
\text { Coalfield }\end{array}$ & Aerial photographs \\
\hline \multirow{2}{*}{$\begin{array}{l}\text { 1:50 } 000 \text { scale mapped landslide } \\
\text { deposits }\end{array}$} & & \multirow{2}{*}{ Isle of Wight } & \\
\hline & & & $\mathrm{PhD} / \mathrm{MSc} / \mathrm{BSc}$ theses \\
\hline Historical field notebooks & \multicolumn{2}{|c|}{$\begin{array}{l}\text { BGS published reports, } \\
\text { sheet explanations and } \\
\text { memoirs }\end{array}$} & Personal communication \\
\hline Historical field slips & \multicolumn{2}{|c|}{$\begin{array}{l}\text { Responsive surveys of } \\
\text { landslides prompted by } \\
\text { media reports }\end{array}$} & $\begin{array}{l}\text { Current and historical media reports } \\
\text { (newspapers, radio and television reports, } \\
\text { internet) }\end{array}$ \\
\hline
\end{tabular}




\section{DATABASE STRUCTURE}

The NLD consists of a series of tables and constraining domains (Fig. 3) held and maintained in a relational Oracle ${ }^{\odot}$ database and ArcGIS9 ${ }^{\odot}$ Geodatabase (a database designed to handle geographic information and spatial data), with a Microsoft Access ${ }^{\odot}$ front end (see above). This is the same approach as that taken by the University of Wollongong for its Landslide Inventory (Flentje et al. 2007); it has the benefit of being able to display spatial information and to store data on a range of attributes. In a similar way, the Slovenian Landslide Database attribute information is stored within an Oracle ${ }^{\odot}$ database, allowing importing of data from multiple sources, whilst the locational data is stored in Oracle Spatial $^{\odot}$ (Komac et al. 2007).

Whilst the use of Microsoft Access $^{\odot}$ results in a very flexible and user-friendly front-end tool for entry and manipulation of data, having the back-end database held in Oracle ${ }^{\circledR}$ provides:

- $\quad$ security - the data is backed up both on- and off-line and is securely held and monitored;

- $\quad$ maintenance and management - Oracle ${ }^{\complement}$ allows the use of powerful tools for the maintenance and control of the data, including the granting of levels of access down to even field level;

- $\quad$ accessibility - the data is readily accessible throughout the BGS and can be readily made available on a wide variety of both on- and off-line platforms;

- $\quad$ use of Oracle Spatial ${ }^{\odot}$ means that the spatial element of the data can be output in any coordinate system required without recourse to complex algorithms or export routines and subsequent manipulation;

- maintenance of history and transactions - the full history of data input, and any changes, is held and can be rolled back to any point;

- the power and capacity of an organisation-wide database, such as Oracle ${ }^{\circledR}$, means that a wide variety of datasets can be readily related to the landslide data, enhancing the potential for new science.

Within Oracle ${ }^{\odot}$, each record represents a survey of a landslide event (temporal or repeat surveys) of a given landslide, not a landslide per se, and thereby allows for the storage, manipulation and extraction of multiple, temporal, landslide events. Multiple movement events and surveys of the same landslide complex are captured as distinct episodes by giving each landslide record a unique identifier consisting of a Landslide ID and a Survey Number. Associated surveys are easily searched for in the database and displayed as separate points in the GIS. When locating these events, the highest point on the crown of the landslide (or digital landslide polygon if crown information is unavailable) is used to avoid operator variance and to be consistent with other national mapping exercises such as the Italian Landslide Inventory (IFFI) (Anon 2008). In addition to the grid reference, information as to how accurately the landslide was located is also included, allowing the user to indicate $\pm x$ metres according to how this information was obtained. Data captured in the field with a hand-held GPS is likely to be accurate to $\pm 10 \mathrm{~m}$ whilst a point located as part of a desk study may be at a scale resulting in an accuracy of $\pm 100 \mathrm{~m}$. The Provenance field states the method of grid reference derivation such as GPS capture, map or report abstraction. These measures were taken to avoid the types of accuracy issues encountered during the population of the DoE database. The DoE database located landslides to a six- or eight-figure grid reference, thereby incorporating an inherent accuracy error of up to $\pm 999 \mathrm{~m}$. The location of landslides to a six-figure grid reference confusingly produced large clusters of points on the corners of grid squares.

These issues of locational accuracy in the DoE database led to some duplication of records, a problem that is controlled by means of a continuous Quality Assurance (QA) process. For the QA of the entries being added to the NLD, the original reference used is sought out and every landslide is then accurately re-positioned. Many of the landslides mapped by BGS before 1990 were included in the DoE database and this grid-reference inaccuracy has resulted in the duplication of many of these records when compared to more modern mapping. 


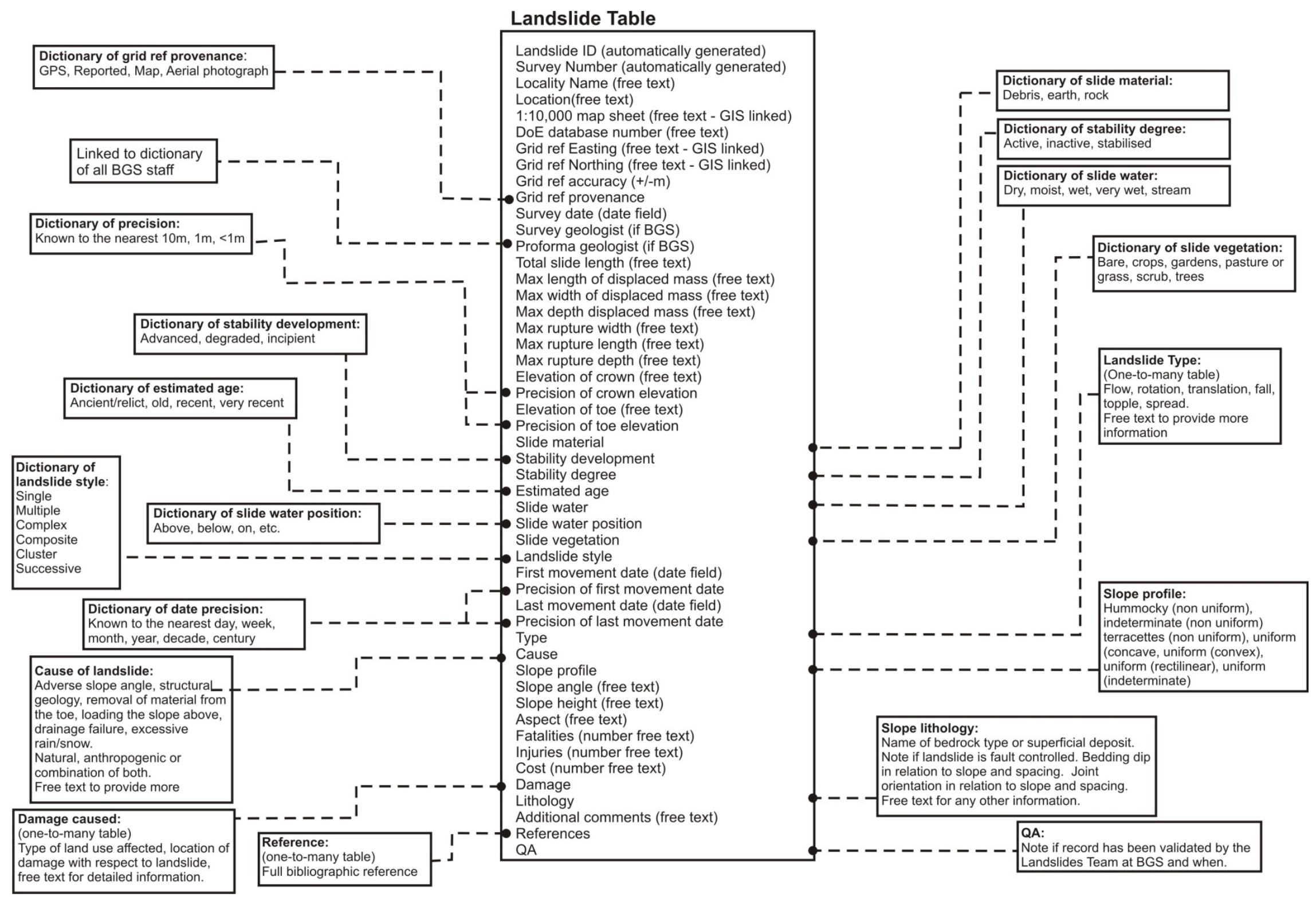

Figure 3. Structure of the National Landslide Database 


\section{DATABASE DICTIONARIES}

Where appropriate, the database dictionaries have been produced using internationally recognised terminology (for example, International Geotechnical Societies' (WP/WLI) 1990), which also allowed some of the DoE database dictionaries to be simplified. In each dictionary table, the database also has fields for 'Not applicable', 'Unknown' and 'Not entered' to accurately account for the absence of data in those fields.

For 'type of landslide' the DoE database dictionary had 35 codes, which incorporated type and style along with material (for example, "multiple rotational rock slide"). In the NLD the dictionary for landslide type follows the conventions set out by Varnes (1978), the EPOCH project (Flageollet 1993) and the WP/WLI (1990). Landslide material, style and type are defined in three separate tables (Tables 2, 3 and 4), which greatly simplify the available definitions and also allows for comparison with international landslide inventories.

Table 2. Dictionary describing the type of engineering material involved in the landslide

\begin{tabular}{|l|l|}
\hline Material & Description \\
\hline Rock & $\begin{array}{l}\text { Engineering rock lithified or indurated to a degree that it cannot be } \\
\text { excavated by digging. }\end{array}$ \\
\hline Debris & $\begin{array}{l}\text { Coarse grained engineering soils dominated by material of gravel size or } \\
\text { greater (including boulders). }\end{array}$ \\
\hline Earth & Fine-grained engineering soils dominated by clay to sand-size fractions. \\
\hline
\end{tabular}

Table 3. Dictionary denoting the landslide movement style

\begin{tabular}{|l|l|}
\hline Style & Description \\
\hline Composite & $\begin{array}{l}\text { A composite landslide exhibits at least two movements simultaneously in } \\
\text { different parts of the displacing mass. }\end{array}$ \\
\hline Complex & $\begin{array}{l}\text { A complex slide involves one of the five main types of movement followed } \\
\text { by two or more of the other main types of movement. }\end{array}$ \\
\hline Successive & $\begin{array}{l}\text { An assembly of individual rotational slips that form a stepped or mosaic } \\
\text { pattern across a slope, with individual slips not sharing displaced material } \\
\text { or a shear surface with its neighbour. }\end{array}$ \\
\hline Cluster & $\begin{array}{l}\text { Cluster or group of small landslides on a section of slope with similar } \\
\text { characteristics. }\end{array}$ \\
\hline Single & A single event failure with no additional movements of the same type. \\
\hline Multiple & $\begin{array}{l}\text { A series of movements of the same type; for example, a series of slices } \\
\text { failing in multiple rotational style. }\end{array}$ \\
\hline
\end{tabular}


Table 4. Dictionary denoting the landslide movement type

\begin{tabular}{|l|l|}
\hline Type & Description \\
\hline Flow & $\begin{array}{l}\text { Slow to very rapid movement of saturated inter-grain movement } \\
\text { predominating over shear surface movements. Initial displacement usually } \\
\text { by sliding, rapidly transforming to flow. }\end{array}$ \\
\hline Rotational slide & $\begin{array}{l}\text { Down slope movement of soil or rock, dominantly on a curved surface of } \\
\text { rupture or relatively thin zones of intense shear strain. The mass may slide } \\
\text { beyond the surface of rupture over the ground surface called a surface of } \\
\text { separation. }\end{array}$ \\
\hline $\begin{array}{l}\text { Translational } \\
\text { slide }\end{array}$ & $\begin{array}{l}\text { Down slope movement of soil or rock, dominantly on a planar surface of } \\
\text { rupture or relatively thin zones of intense shear strain. The mass may slide } \\
\text { beyond the surface of rupture over the ground surface, which becomes a } \\
\text { surface of separation. }\end{array}$ \\
\hline Fall & $\begin{array}{l}\text { Detachment of soil or rock from a steep slope with little or no shearing. } \\
\text { Descent mainly through air by falling, bouncing or rolling. Rapid to } \\
\text { extremely rapid. Initial detachment may be by sliding or toppling. }\end{array}$ \\
\hline Topple & $\begin{array}{l}\text { Forward rotation out of the slope of soil or rock about a point or axis below } \\
\text { the centre of gravity of the displaced mass. Extremely slow to extremely } \\
\text { rapid sometimes accelerating throughout the movement. }\end{array}$ \\
\hline Undefined & Undefined \\
\hline
\end{tabular}

The age and activity of a landslide are important factors to record within a landslide inventory. Temporal landslide data is as important to understanding the geomorphic evolution of an area as the spatial distribution of slides. If the ultimate aim is to produce a landslide hazard map then knowledge of the temporal activity of landsliding is key. Similarly, the link between periods of landslide activity and climate is also of great interest, especially in the light of future changes in climate and the impact of this on landslide activity. However, it is extremely difficult to date ancient landslide events with any degree of accuracy and, as such, the ages assigned to landslides only provide an arbitrary indication of age. The DoE database had definitions for age and activity but this was limited to recent or relict and active or passive. The WP/WLI (1990) regrouped the Varnes (1978) definitions on age and activity under the following headings: 'state of activity,' 'distribution of activity' and 'style of activity.' Whilst the NLD follows the style of activity definitions, it has simplified the state of activity terms defined by Varnes (1978) into active, inactive and stabilised whilst also adding descriptions on the state of development (Tables 5 and 6). Whilst activity state and style have been described in the WP/WLI definitions, age has been somewhat neglected. BGS produced the definitions in Table 7, which are similar to those defined by Berkland (1977). Temporal data for modern landslides, observed either at the time of the event or through comparison of aerial photographs and geological mapping, is included in the NLD.

The WP/WLI (1990) published a suggested method for reporting landslide causes based upon preparatory and triggering factors. The WL/WPI gave a list of causes under four headings: ground conditions, geomorphic processes, physical processes and man-made processes. Many of the causes under these headings are not applicable to Great Britain, for example, volcanic eruptions, thawing of permafrost and breaching of crater lakes. Often it is difficult to assess what has caused the triggering of a landslide, especially if the event has not been witnessed. To record cause, the NLD has incorporated both triggering and preparatory factors but limited these to those which are most likely to be identifiable and relevant in Great Britain (Table 8).

Table 5. Dictionary describing the degree of slope stability

\begin{tabular}{|l|l|}
\hline Stability degree & Description \\
\hline Active & $\begin{array}{l}\text { Landslide was moving at time of observation (field visit) or when reported } \\
\text { and entered into database (reported occurrence) }\end{array}$ \\
\hline Inactive & Landslide was not moving at time of visit or report. \\
\hline Stabilised & Landslide has been active but is now stabilised by remedial action. \\
\hline
\end{tabular}


Table 6. Dictionary describing the state of development of the landslide

\begin{tabular}{|l|l|}
\hline $\begin{array}{l}\text { Stability } \\
\text { development }\end{array}$ & Description \\
\hline Incipient & $\begin{array}{l}\text { Fresh, small, landslide features are present such as scarplets, open cracks } \\
\text { and bulges and conditions indicate that movement will progress and } \\
\text { increase unless conditions change to enhance stability. }\end{array}$ \\
\hline Advanced & $\begin{array}{l}\text { Major landslide features such as scarps, falls, rotated blocks and flows are } \\
\text { well developed. }\end{array}$ \\
\hline Degraded & $\begin{array}{l}\text { Landslide features are eroded, smoothed and vegetated with little, if any } \\
\text { signs, of recent activity. }\end{array}$ \\
\hline
\end{tabular}

Table 7. The estimate age of the landslide. This is particularly useful where the date of the landslide is unknown.

\begin{tabular}{|l|l|}
\hline Age & Description \\
\hline Very recent & $\begin{array}{l}<10 \text { Years Old. Remembered locally, features still very fresh occurred } \\
\text { under current climatic conditions. }\end{array}$ \\
\hline Recent & $\begin{array}{l}<100 \text { Years Old. Recorded locally, somewhat degraded, occurred under } \\
\text { current climatic conditions. }\end{array}$ \\
\hline Old & $\begin{array}{l}\text { (<1000 Years Old). Landslide event unlikely to have been recorded unless } \\
\text { significant magnitude may have occurred under different climatic } \\
\text { conditions to the present and be in a relict condition. }\end{array}$ \\
\hline Ancient/relict & $\begin{array}{l}\text { (>1000 Years old }) \text { Landslide event prehistoric, in a relict condition and } \\
\text { occurred under different climatic conditions to the present time. }\end{array}$ \\
\hline
\end{tabular}

Table 8. Dictionary of landslide causal factor

\begin{tabular}{|l|l|}
\hline Causal Factor & Description \\
\hline Angle & Failure due, in whole or in part, to an adverse slope angle. \\
\hline Lithology & $\begin{array}{l}\text { Failure due, in whole or in part, to the presence of a lithology known to be } \\
\text { susceptible to slope instability such as high plasticity clay. }\end{array}$ \\
\hline Structure & $\begin{array}{l}\text { Failure due, in whole or in part, to adverse structural features such as } \\
\text { discontinuities or folding. }\end{array}$ \\
\hline Removal of & $\begin{array}{l}\text { Failure due, in whole or in part, to the removal of material from the bottom } \\
\text { of a slope or part of a slope by excavation or erosion. }\end{array}$ \\
\hline Loading & $\begin{array}{l}\text { Failure due, in whole or in part, to loading of the top of a slope or part of a } \\
\text { slope by the natural or artificial placement of extra material on the slope. }\end{array}$ \\
\hline Drainage & $\begin{array}{l}\text { Failure due, in whole or in part, to increase in pore water pressure due to } \\
\text { impaired drainage from, or drainage disposal into, the slope. }\end{array}$ \\
\hline Rainfall & $\begin{array}{l}\text { Failure due, in whole or in part, to increase in pore water pressure due to a } \\
\text { high magnitude rainfall event. }\end{array}$ \\
\hline
\end{tabular}

\section{NATIONAL LANDSLIDE DATABASE GIS}

Within the BGS, GIS is an everyday tool for earth science research and investigations. The NLD is 'dynamically-linked' to the aforementioned Oracle ${ }^{\complement}$ database using ArcMap ${ }^{\complement}$ 9.2. The use of ArcGIS allows the user to view and query the database while useing in-house GIS tools to manipulate the database points and carry out QA procedures. After login, the GIS creates a 
temporary shapefile representing the NLD at that point in time. This allows multiple users to work safely on the database simultaneously. GIS tools have been developed to make particular procedures, such as Quality Assurance (QA), more efficient. These include a tool that enables landslide database points to be moved to a more accurate location by dragging and dropping a selected point (landslide) to a new location. Once the tool is activated and a point moved, the GIS automatically writes an update query to the landslide database stating which point has been selected and what the new coordinates of the point are. In effect, any changes to the location of a landslide are immediately updated in the database. Figures 4 and 5 show an example landslide, Canyard's Hill, in the National Landslide Database and its associated point in the GIS.

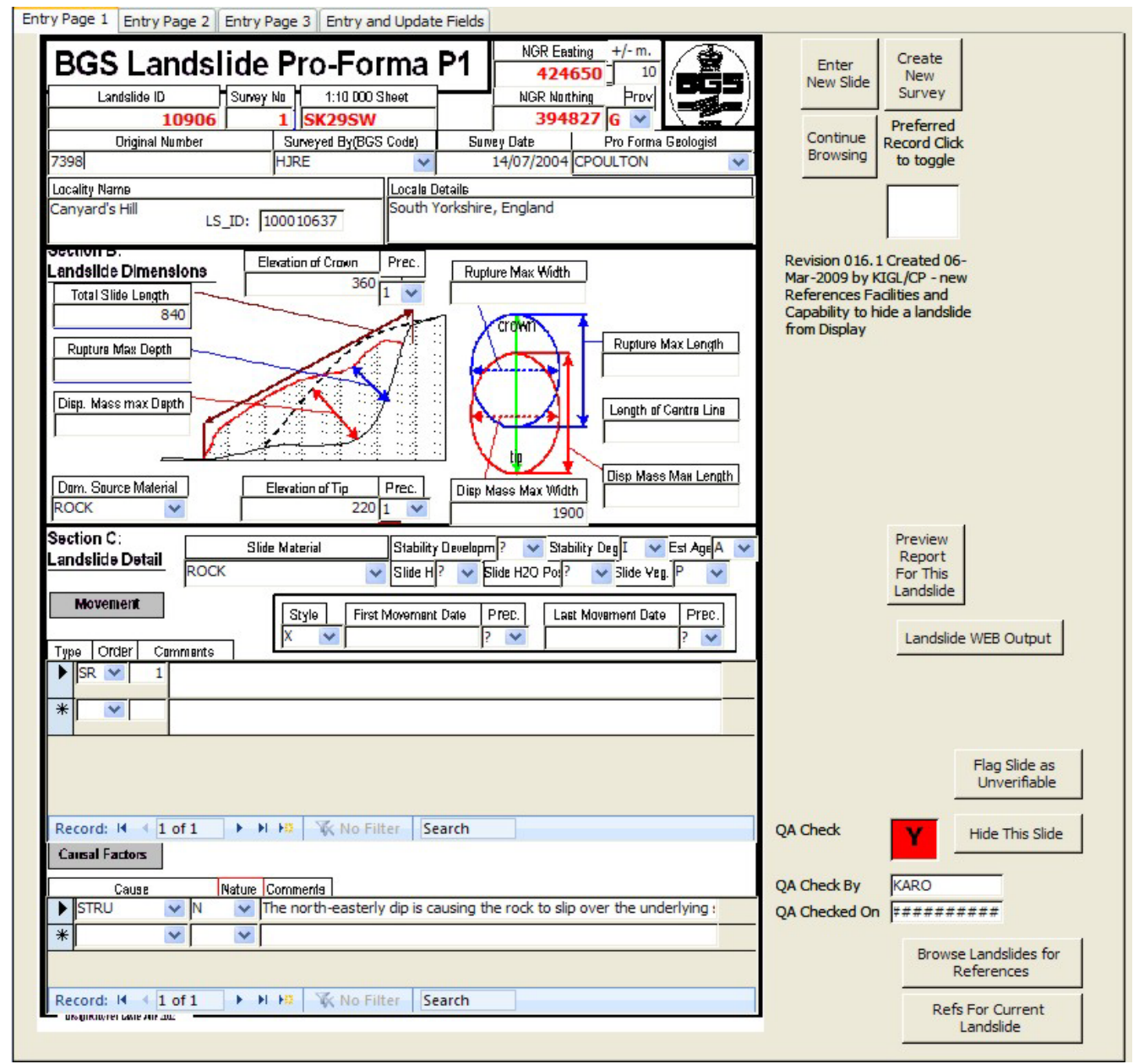

Figure 4. Page 1 of the National Landslide Database pro-forma for an example landslide in South Yorkshire 


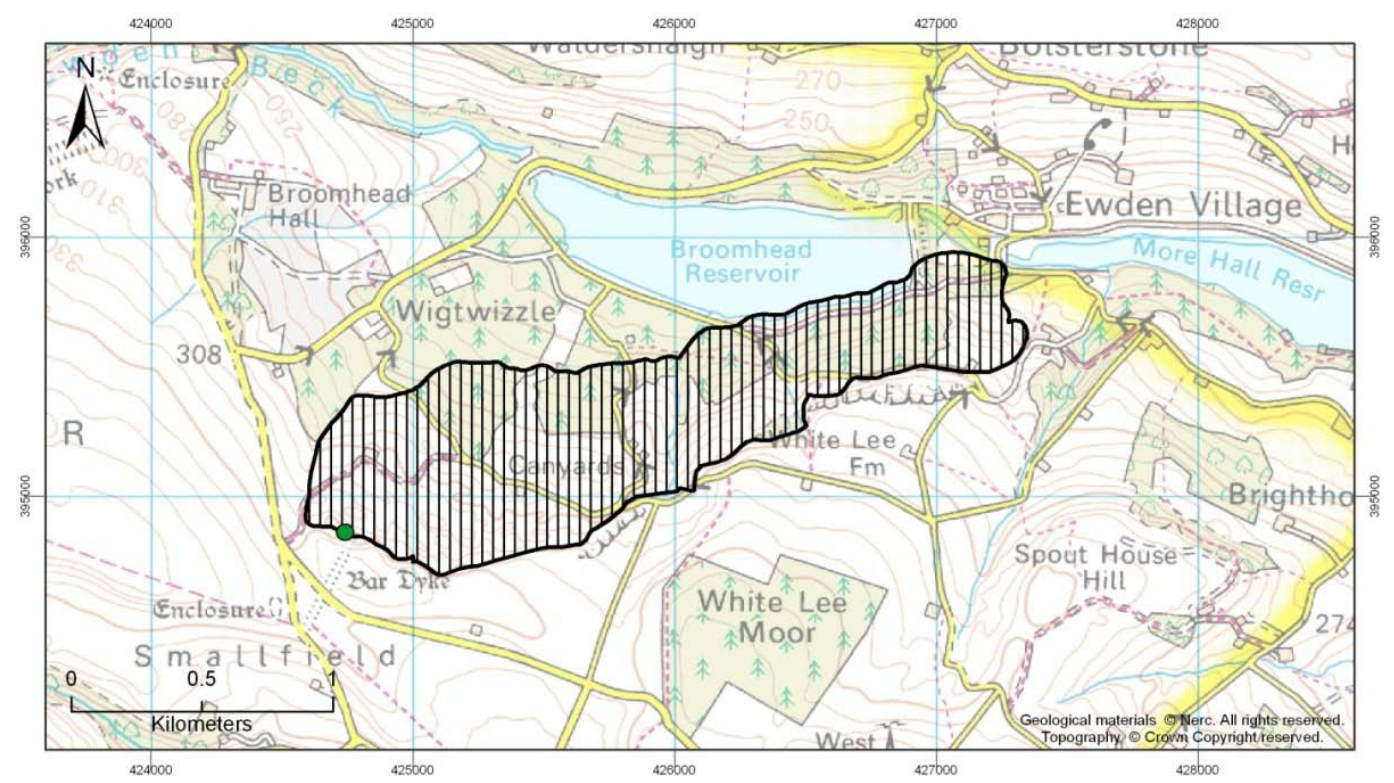

Figure 5. Canyard's Hill landslide showing BGS DiGMap10 polygon (vertical black hatching) and associated National Landslide Database point (green point). OS topography $\odot$ Crown Copyright. All rights reserved. 100017897/2010

Future plans involve making selected information from the NLD freely available to the public through the BGS on-line GIS - the GeoIndex (www.bgs.ac.uk/GeoIndex). This will be a simplified version and include grid reference, name, location and a bibliographic reference to the source information.

\section{APPLICATIONS}

The NLD is an important component of the BGS's national landslide susceptibility assessment. Assessing an area's susceptibility to landsliding requires knowledge of the distribution of failures but also an understanding of the causative factors and their spatial distribution. Although the NLD has greatly increased the number of known locations of past instability and areas of frequently occurring slope movements, it is not suitable for identifying first time failures especially if there are no previously-recorded landslides. To bridge the gap between the data points, a landslide susceptibility map has been developed as part of the GeoSure dataset of national geohazard susceptibility maps (Walsby 2007, 2008). In addition to landsliding, this suite of six maps identifies susceptibility to shrink-swell, compressible ground, collapsible ground, dissolution and running sand. The GeoSure methodology uses expert judgement to assess and classify the susceptibility of a geological formation and to determine the likely causative factors of landsliding. Modelling of the causative factors involved in landsliding has been made possible through the use of GIS due to its ability to spatially display and manipulate data on causative factors (Soeters \& Van Westen 1996).

\section{DISCUSSION}

The first landslide inventory for Great Britain (the DoE database) was created as part of a three year applied research contract from the government department responsible for national planning policy. The contract was one of several "national reviews of the physical problems that could seriously affect land and their relevance to development and planning” (Brook 2002). It was awarded competitively to a private sector consultant (Geomorphological Services Ltd) in the mid 1980s. Other contracts covered mining instability (Arup Geotechnics, 1991), natural underground cavities (Applied Geology Ltd. 1993), adverse foundation conditions (Wimpey Environmental and NHBC 1995), erosion, deposition and flooding (Rendel Geotechnics, 1995) and natural contamination (Appleton 1995). The reviews were intended to cover several topics of which determining the distribution of the geohazard was one. At the time of the landslide review (Geomorphological Services Ltd. 1986/87), Personal Computers (PCs) had only relatively recently become available when the inventory was compiled and their storage capacity was limited and available software rather basic. In addition, the engineering geological and geotechnical 
community was only just developing common internationally-accepted terms to define and describe landslides. As a result, the DoE database, which was created digitally, had a significant number of limitations, which have been discussed above.

While one of the main purposes of the DoE landslide review was to make local authorities aware of the presence of landslides in their areas; the way in which the inventory was compiled (desk study only) meant that only a proportion of the existing landslides were included. This was not, in itself, a serious deficiency as the intention was to increase awareness, not to compile a complete inventory. However, initially, there was an intention that the research contractor would maintain the inventory by using income from the sale of data to fund the acquisition and entry of further information on landslide events. As it turned out, there was never sufficient income to achieve this and through the 1990s, the inventory became increasingly moribund. Eventually, towards the end of the 1990s, the DoE agreed to make the whole original database available to certain organisations that requested it. The BGS was one of those organisations that did so.

The BGS then invested a considerable amount of money to develop the wholly new database that is described above. The aim was to create a modern, time-proof landslide database that would be technologically future-proof, professionally managed and maintained, updated regularly with new information and available for use by the public (though not necessarily free). The database fitted well with the vision of the BGS at the time: national, strategic and long-term. In the event, the limited resources available have meant that it took a number of years to design the database. Then, when the DoE database was examined with a view to transferring the data directly into the NLD, it was found that the data were in an unsuitable form and most of the entries had to be checked against the source material and entered into the NLD from scratch. As a result, it has taken several more years to increase the number of entries from the original total of just under 9000 to the present one of just over 15000 . As discussed above, new data are entered from a variety of source, including primary survey.

The advantage of the NLD is that it is publicly available, properly managed and actively updated and maintained; currently, it is not dependant on income from enquirers for its survival. This is clearly an advantage of the database being maintained by an organisation that has a long term commitment to manage geoscientific data for the nation.

As indicated above, the NLD forms part of a strategy to provide information on geohazard occurrence and to indicate the relative susceptibility of the ground to a range of geohazards. A companion database for karst features has also been developed (Cooper et al., 2001; Cooper, 2008; Farrant \& Cooper, 2008). In addition, a digital register (index or catalogue) of all known non-coal underground mine plans, sections and entrances has been compiled by the BGS and other bodies such as the Health and Safety Executive, The National Archives, The Coal Authority, the Mineral Valuer (part of The Valuation Office Agency), and the Camborne School of Mines (http://www.bgs.ac.uk/nocomico/home.html). Similar information for coal mines and workings is held by The Coal Authority. Therefore, an inventory of the occurrence of the main natural and artificial geohazards is slowly being developed and made available for a wide range of users.

\section{CONCLUSIONS}

It has taken nearly 25 years for a satisfactory landslide database for Great Britain to be designed and populated. The original idea was formulated at a time when the computer hardware and software available was not wholly suitable for the task of developing a national, accessible landslide inventory. The National Landslide Database uses internationally available software Oracle $^{\circledR}$ for the data storage, Microsoft Access ${ }^{\odot}$ as a 'front-end' for easy data entry and ArcGIS to allow the user to view and query the database, as well as enabling data managers to manipulate the database points and carry out QA procedures. The database fields used and the dictionaries that define entry into those fields come mostly from recognised international standards.

Information on landslides comes from a wide range of sources including the scientific literature, geological maps, the news media and primary survey. It is intended to maintain the database in perpetuity as part of the BGS's 'public good' National Capability, subject to funding remaining available. The NLD is one of several national, natural and artificial geohazard inventories and provides information to enhance the interpretation of geohazard susceptibility across the country. 


\section{ACKNOWLEDGEMENTS}

This paper is published with the permission of the Executive Director of the British Geological Survey (NERC). The authors owe a debt to Dave Brook and Brian Marker, both formerly of the Department of the Environment and its successors, who had the original idea to develop a National Landslide Database and to former staff at Geomorphological Services Ltd. who developed the first version. Alan Forster and Andrew Gibson (both formerly BGS) are also thanked.

\section{REFERENCES}

Anon., 2008. Landslides in Italy. Special Report 83/2008. Institute for Environmental Protection and Research, Rome.

Appleton, JD. 1995. Radon, methane, carbon dioxide, oil seeps and potentially harmful elements from natural sources and mining areas: relevance to planning and development in Great Britain Summary Report. Technical Report WP/95/4. British Geological Survey, Keyworth, Nottingham.

Applied Geology Ltd. 1993. Review of instability due to natural underground cavities in Great Britain. Report to the Department of the Environment, 14 volumes. Applied Geology Ltd., Royal Leamington Spa.

Arup Geotechnics. 1991. Review of mining instability in Great Britain. Report to the Department of the Environment, 25 volumes. Arup Geotechnics, Newcastle-upon-Tyne.

Berkland, J.O. 1977. Landslide chronology - the need for standardization. Geological Society of America, Abstracts with Programs, 9, 4, 388.

British Geological Survey. 2009a. Landslides on the A85 road, Glen Ogle, Lochearnhead, Stirlingshire, www.bgs.ac.uk/science/landuseanddevelopment/landslides/GlenOgle.html, [Accessed 29 November 2009].

British Geological Survey. 2009b. Landslide at Knipe Point, Cayton Bay, North Yorkshire, www.bgs.ac.uk/science/landuseanddevelopment/landslides/CaytonBay.html, [Accessed 29 November 2009].

British Geological Survey. 2009c. Landslide at Lyme Regis, Dorset, www.bgs.ac.uk/science/landuseanddevelopment/landslides/LymeRegis.html, [Accessed 29 November 2009].

Brook, D. 2002. Land use planning as an element in risk management. In: McInnes, R.G., \& Jakeways, J. (eds.), Instability: planning and management: seeking sustainable solutions to ground movement problems. Proceedings of the International Conference organised by the Centre for the Coastal Environment, Isle of Wight Council. Ventnor, Isle of Wight. Thomas Telford, London. 127-134.

Casagli, N., Catani, F., Puglisi, C., Delmonaco, G., Ermini, L. \& Margottini, C. 2004. An inventory-based approach to landslide susceptibility assessment and its application to the Virginio River Basin, Italy. Environmental and Engineering Geoscience, 10 (3), 203-216.

Chandler, R.J. 1970. The degradation of Lias Clay Slopes in an area of the East Midlands: Quarterly Journal of Engineering Geology, 2, 161 - 181.

Conway, B.W., Forster, A., Northmore, K.J., \& Barclay, W. 1980. South Wales Coalfield Landslip Survey. British Geological Survey Technical Report EG/80/4, London.

Cooper, A.H. 2008. The GIS approach to evaporite-karst geohazards in Great Britain. Environmental Geology, 53(5), 981-992.

Cooper, A.H., Farrant, A.R., Adlam, K.A.M. \& Walsby, J.C. 2001. The development of a national Geographic Information System (GIS) for British karst geohazards and risk assessment. In: Beck, B.F. \& Herring, J.G. (eds.), Geotechnical and Environmental Applications of Karst Geology and Hydrology, 125-130. AA Balkema, Lisse.

CRED. 2009. The International Disaster Database. Centre for Research on the Epidemiology of Disasters, Brussels. www.emdat.be/database (accessed 9 February 2010)

Cruden, D.M. \& Brown, W. 1992. Progress towards the world landslide inventory. In: Bell, D.H. (ed), Proceedings of the 6th International Symposium on Landslides, Christchurch, New Zealand. A.A. Balkema, Rotterdam. 1, 59-64. 
Dai, F. \& Lee, C. 2002. Landslide characteristics and slope instability modeling using GIS, Lantau Island, Hong Kong. Geomorphology, 42(3-4), 213-228.

Dikau, R., Brunsden, D., Schrott, L. \& Ibsen, M.L. (eds.) 1996. Landslide recognition: identification, movement and causes. Wiley \& Sons, Chichester.

Department of the Environment (DoE). 1990. Planning Policy Guidance: Development on unstable land. PPG14. Her Majesty’s Stationery Office, London.

Department of the Environment (DoE). 1996. Planning Policy Guidance: Development on unstable land: landslides and planning. PPG 14 (Annex 1). Her Majesty’s Stationery Office, London.

Doornkamp, J.C., Griffiths, J.S., Lee, E.M., Tragheim, D. \& Charman, J.H. 1988. Planning and Development: Applied Earth Science Background: Torbay. Report for the Department of the Environment. 1 volume plus 10 maps. Geomorphological Services (Publications and Reprographics) Ltd. Newport Pagnell, UK.

Duman, T.Y., Can, T., Emre, O., Kecer, M., Dogan, A., Ates, S. \& Durmaz, S. 2005. Landslide inventory of northwestern Anatolia, Turkey. Engineering Geology, 77(1-2), 99-114.

Early, K.R. \& Skempton, A. 1972. Investigation of the landslide at Walton's Wood, Staffordshire. Quarterly Journal of Engineering Geology, 5, 19-41.

Flageollet, J.C. (ed). 1993. The temporal occurrence and forecasting of landslides in the European community. Report of the EPOCH Project. Contract No. 90 0025, 3 Volumes.

European Environment Agency. 2003. Mapping the impacts of recent natural disasters and technological accidents in Europe. Environmental Issue Report No 35. European Environment Agency, Copenhagen. 54p. (Download: http://www.preventionweb.net/files/672 7808.pdf,

[Accessed 29 November 2009]

European Space Agency. 2005. Giant robot helps prevent landslides. http://www.esa.int/esaMI/Technology_Transfer/SEM9R03AR2E_0.html [Accessed 29 November 2009]

Farrant, A.R \& Cooper, A.H. 2008. Karst geohazards in the UK: the use of digital data for hazard management. Quarterly Journal of Engineering Geology and Hydrogeology Vol. 41. 339-356

Fish, P., Carey, J. \& Moore, R. 2006 Landslide geomorphology of Cayton Bay, North Yorkshire. Proceedings of the Yorkshire Geological Society, 56(1), 5-14.

Flentje, P., Stirling, D. \& Chowdhury, R.N. 2007. Landslide susceptibility and hazard derived from a landslide inventory using data mining - an Australian case study. In: Proceedings of the $1^{\text {st }}$ North American Landslide Conference, Landslides and Society: Integrated Science, Engineering, Management, and Mitigation. Vail, Colorado. On CD-ROM, Paper number 17823-024, 10p.

Galli, M. \& Guzzetti, F. 2007. Landslide vulnerability criteria: a case study from Umbria, Central Italy. Environmental Management, 40, 649-664.

Geomorphological Services Limited (GSL). 1986/7. Review of research into landsliding in Great Britain. Report to the Department of the Environment, 15 volumes. Geomorphological Services (Publications and Reprographics) Limited, Newport Pagnell.

Geomorphological Services Limited (GSL). 1989. Landslide data bank for Britain: user manual version 1.0. Geomorphological Services (Publications and Reprographics) Limited, Newport Pagnell.

Guzzetti, F., Ardizzone, F., Cardinali, M., Galli, M., Reichenbach, P. \& Rossi, M. 2008.

Distribution of landslides in the Upper Tiber River basin, central Italy. Geomorphology, 96(1-2), 105-122.

Hutchinson, J.N. 1976. Coastal landslides in cliffs of Pleistocene deposits between Cromer and Overstrand, Norfolk, England. In: Janbu, N., Jorstad, F. \& Kjaernsli, B. (eds.), Laurits Bjerrum Memorial Volume, Contributions to Soil Mechanics. Norwegian Geotechnical Institute, Oslo, 155182.

International Consortium on Landslides (ICL). 2006. International Consortium on Landslides:

Database of Landslides of the World, (http://www2.co-conv.jp/ landslide/v2/landslide/simple.php, 4.11.2007), [Accessed 29 Nov 2009]. 
Jelínek, R., Wood, M. \& Hervás, J. 2007. Landslide mapping and landslide data in new member states. Report of the European Commission, Joint Research Centre, Institute for the Protection and Security of the Citizen, Ispra, Italy. EUR 22950 EN. Office for Official Publications of the European Communitiesss, Luxembourg.

(http://eusoils.jrc.ec.europa.eu/ESDB_Archive/eusoils_docs/other/EUR22950.pdf) [Accessed 29 November 2009]

Jordan, C. J., 2009. BGS·SIGMAmobile; the BGS Digital Field Mapping System in Action. Digital Mapping Techniques 2009 Proceedings, May 10-13, Morgantown, West Virginia, USA, Vol. U.S. Geological Survey Open-file Report.

Jordan, C. J., Bee, E. J., Smith, N. A., Lawley, R. S., Ford, J., Howard, A. S., and Laxton, J. L., 2005. The development of digital field data collection systems to fulfil the British Geological Survey mapping requirements. GIS and Spatial Analysis: Annual Conference of the International Association for Mathematical Geology, Toronto, Canada, York University, 886-891.

International Geotechnical Societies’ UNESCO Working Party on World Landslide Inventory (WP/WLI). 1990. A suggested method for reporting a landslide. Bulletin of the International Association of Engineering Geology, 41, 5-12.

Jones, D.K.C. 1998. Landsliding in the Midlands: a critical evaluation of the contribution of the National Landslide Survey. East Midland Geographer, 21/22, 106-125.

Jones, D.K.C. \& Lee, E.M. 1994. Landsliding in Great Britain. Department of the Environment, London.

Komac, M., Fajfar, D., Ravnik, D.\& Ribi`ei`e, M. 2007 Slovenian National Landslide Database a promising approach to slope mass movement prevention plan. Geologija, 50(2), 393-402.

Lee, E.M. \& Jones, D.K.C. 2004. Landslide risk assessment. Thomas Telford, London.

McGuire, B., Mason, I. \& Kilburn, C. 2002. Natural hazards and environmental change. Arnold, London.

Osuchowski, M. \& Atkinson, R.. 2008. Connecting diverse landslide inventories for improved information in Australia. In: Casagli, N., Fanti, R. \& Tofani, V. (eds.), Proceedings of the First World Landslide Forum, Tokyo, Japan, 67-70. (http://150.217.73.85/wlfpdf/02_Osuchowski.pdf) [Accessed 29 November 2009]

Rendel Geotechnics. 1995. Erosion, deposition and flooding in Great Britain - a summary report. Rendel Geotechnics, London.

Skempton, A. \& Weeks, A. 1976 The Quaternary history of the Lower Greensand escarpment and Weald Clay vale near Sevenoaks, Kent. Philosophical Transactions of the Royal Society, A, 283, 493-526.

Soeters, R. \& Van Westen, C.J. 1996. Slope instability recognition, analysis and zonation. In: Transportation Research Board Special Report 247, National Research Council, National Academy Press, Washington, D. C., 129-177.

Turcotte, D.L., Malamud, B.D., Guzzetti, F. \& Reichenbach, P. 2005. A general landslide distribution: further examination, In: Hungr, O., Fell, R., Couture, R. \& Eberhardt, E. (eds.), Landslide Risk Management, Vancouver, Canada. Taylor \& Francis, London. 675-680.

Varnes, D. 1978. Slope movement types and processes. In: Schuster, R.L. \& Krizek, R.J. (eds.), Transportation Research Board Special Report 176: Landslides: Analysis and Control. National Research Council, Washington D.C., 11-33.

Walsby, J.C. 2007. Geohazard information to meet the needs of the British public and governmental policy. Quaternary International, 171/172, 179-185.

Walsby, J.C. 2008. GeoSure; a bridge between geology and decision-makers. In: Liverman, D.G.E., Pereira, C.P.G. \& Marker, B. (eds.) Communicating environmental geoscience. Geological Society, London, Special Publications, 305, 81-87.

Wimpey Environmental \& NHBC. 1995. Foundation conditions in Great Britain: a guide to planners and developers. 2 volumes. Wimpey Environmental, Hayes, Middlesex, UK.

Winter, M., Macgregor, F. \& Shackman, L. (eds.) 2005. Scottish road network landslide study. The Scottish Executive, Edinburgh. 